\title{
Recognition of sentences in silence, and at noise, in free Field, in carriers from hearing loss from moderate degree
}

\section{Reconhecimento de sentenças no silêncio e no ruído, em campo livre, em indivíduos portadores de perda auditiva de grau moderado}

\author{
Alexandre Hundertmarck Lessa', Cristiane Bertolazi Padilha², Sinéia Neujahr dos Santos ${ }^{3}$, Maristela Julio Costa4. \\ 1) Master's Degree Student. Speech Therapist. \\ 2) Master in Human Communication Disorder at Federal University of Santa Maria. Speech Therapist. \\ 3) PhD Student. Speech Therapist; PhD Student in Human Communication Disorder. \\ 4) $\mathrm{PhD}$ in Human Communication Disorder at Federal University of São Paulo. Adjunct Professor of Speech Therapist at Federal University of Santa Maria. \\ Institution: Federal University of Santa Maria \\ Santa Maria / RS - Brasil. \\ Mailing Address: Alexandre Hundertmarck Lessa - Conde de Porto Alegre Street, 961, Apt. 801 - Centro - Santa Maria / RS - Brasil - Zip-code: 97015-110 - Telephone: \\ (+55 55) 8432-9337 - E-mail: alexandrehl@ gmail.com \\ Article received in 2011 April $26^{\text {th }}$. Article approved in 2011 August $29^{\text {th }}$.
}

\section{SUMMARY}

Introduction: In daily routine from the audiologists, the complaints are frequent about the difficulty of understanding of speech in a noisy environment. Audiologic tests that use the sentences as stimulus, have been objects of research, because besides check the real hearing abilities from the patient, provide a direct approach with situations of communications and provide information that will guide the more adequate conduct to be indicated for the individual with hearing complaints.

Objective: Determine the thresholds of recognition of sentences in silence and the relation sign/noise in a group of individual carriers of the bilateral neurosensory hearing loss and symmetric from moderate degree.

Method: Retrospective study, clinic and experimental. Were evaluated 50 individuals, being 16 adults of middle age and 34 elderly. Was performed a anamnesis and the basic audiological evaluation. Posteriorly, using the test of List of Sentences in Portuguese, was performed the research of the thresholds of recognition of sentences in silence and the relation sign/noise with a fixed level of noise of $65 \mathrm{~dB}$ NPS(A).

Results: The average LRSS obtained for all subject was of $60,90 \mathrm{~dB}$ NPS (A), and the average of relations S/R was of $+3,20 \mathrm{~dB}$ NPS (A).

Conclusion: The analysis of variables allowed to obtain the average LRSS, affirm that it had correlation with the triton mean of the better ear from subjects and that the threshold of audibility seems to be the only parameter to influence the recognition in the silence. Besides, make it possible to obtain of the mean of relations $\mathrm{S} / \mathrm{R}$, which demonstrate the difficulty that the individual with hearing loss present in noisy environment.

Keywords: hearing, neurosensory hearing loss, noise, perception of speech.

\section{RESUMO}

Introdução: Na rotina clínica do audiologista, são frequentes as queixas de dificuldade de compreensão de fala em ambiente ruidoso. Testes audiológicos que utilizam sentenças como estímulo, têm sido objetos de pesquisa, pois além de verificarem real habilidade auditiva do paciente, proporcionam uma aproximação direta com situações de comunicação e fornecem informações que orientarão a conduta mais adequada a ser indicada para o indivíduo com queixa auditiva.

Objetivo: Determinar os limiares de reconhecimento de sentenças no silêncio e a relação sinal/ruído em um grupo de indivíduos portadores de perda auditiva neurossensorial bilateral e simétrica de grau moderado.

Método: Estudo retrospectivo, clínico e experimental. Foram avaliados 50 indivíduos, sendo 16 adultos de meia idade e 34 idosos. Realizou-se anamnese e avaliação audiológica básica. Posteriormente, utilizando o teste Listas de Sentenças em Português, realizou-se a pesquisa dos limiares de reconhecimento de sentenças no silêncio e a relação sinal/ruído com um nível fixo de ruído de 65 dB NPS(A).

Resultados: O LRSS médio obtido para todos os sujeitos foi de 60,90 dB NPS(A), o e a média das relações S/R foi de $+3,20$ dB NPS(A).

Conclusão: A análise das variáveis permitiu obter o LRSS médio, afirmar que este teve correlação com a média tritonal da melhor orelha dos sujeitos e que o limiar de audibilidade parece ser o único parâmetro a influenciar o reconhecimento no silêncio. Além disso, possibilitou a obtenção da média das relações $\mathrm{S} / \mathrm{R}$, a qual demonstra a dificuldade que o sujeito com perda auditiva apresenta em ambientes ruidosos.

Palavras-chave: audição; perda auditiva neurossensorial; ruído; percepção da fala. 


\section{INTRODUCTION}

Analyzing the capacity to recognize the speech sign became increasingly fundamental in the process of audiological evaluation, due to the frequent complaint of individuals in recognizing the speech.

Therefore, tests with speech stimuli have become objects of research, because, in addition to check the real auditory ability of the patient, provide a direct approach to daily communication situation. In this way, they provide information that will guide to the most adequate conduct to be indicated to the individual with auditory disorder complaint.

Due to the importance of availability of the means to evaluate and to know individual capacity to discriminate the speech in various daily situation and the concern to measure the skill in which is closer to the daily situations (1), tests which use sentences to evaluate the speech recognition, whether in silence, or at the presence of competitive noise, have been developed in different countries, about more than two decades. Through the characteristics evaluated tests consisting of this type of stimulus can be considered the best instruments to evaluate the communication of individuals with auditory disorder complaint.

It's known that auditory integrity is fundamental to the communication process and the greater is the auditory impairment, the greater are the difficulties to the individual to comprehend the speech. When we evaluated the hearing of individuals with auditory loss, it became extremely important to use the speech tests which represent the daily communication situations, which enables us to obtain more information about the real difficulties of the evaluated individuals.

Even given the importance of its findings to a more accurate clinical diagnosis, the tests in recognizing the sentences in the noise it is still not part of clinical routine among all of the professionals and, many times, the speech therapist ceases to use them as they don't possess the parameters to interpret or classify the obtained results.

For a long time, patients with auditory loss did not receive the specific orientation to minimize their difficulties after a conventional audiometric evaluation, once the tests used so far, studied only the tone thresholds and recognition thresholds of isolated words and without presence of noise and therefore, it did not showed the real difficulty that was presented day them.

Basing on these considerations, the goal of this research was to determine the recognition threshold of the sentences in quiet (SRTs), in free field, and the relation signal/nose $(\mathrm{S} / \mathrm{N})$, in group of a middle-aged adults and elderly individuals, bearers of neurosensory hearing loss of moderate degree, and relate the triton mean in these individuals through the value found on SRTs, in order to relate these findings with communicative performance.

\section{METHOD}

This study was conducted at Hearing Prostheses Laboratory (HPL) of Speech and Hearing Pathology Service (SHPS) of Federal University of Santa Maria (UFSM).

The research is a subproject of major Project entitled as Research and Database Health Hearing, registered at the Office Projects in the Sciences Health Center, under the $\mathrm{n}^{\mathrm{o}}$ 019731 and approved by the Research Ethics Committee of UFSM with certificate of $n^{\circ}$ 0138.0.243.246-06, in 2006/ 12/05.

The procedures performed in this research are described in detail as follows.

\section{Test environment, equipment and calibration}

The measures of this study were obtained in acoustically treated cabin, using two channels digital audiometer, brand Fonix, model FA-12, type I; also earphones type TDH- 39 P, brand Telephonics; and amplification system with two speakers of brand CCE, with power 100 watts to measure in free field.

The equipment calibration to obtain the measures in free field was performed previously in a place where the patient would be positioned, i.e., one meter from the speakers, at $0^{\circ}, 0^{\circ}$ azimute degree, by a professional qualified for this service, registered at Inmetro São Paulo, it was measured using Sound Pressure Level (SPL), using the scale A of the meter, with quick responses, as it is considered the most closely matches the human auditory response, besides being used by the most researchers in this field (3).

Moreover, during the whole research, the measures in free field, was monitored by the examiner by the aid of a Digital Pressure Sound Meter, of brand Radio Shack, considering the test signal characteristics and the necessity to keep always the same conditions to the acoustic environment.

In order to establish the calibration parameters of the channel sentences, it was used as a reference a purê 
tone present in the first track of the Compact Disc (CD). The use of the puretone was necessary, as the speech is a complex sound, which presents a great variation between the more intense sound to the less intense (5). Thus, the use of a continuous tone reference, ensured that the conditions of presentation of speech stimuli were kept constant.

On the other hand, to calibrate the noise, presented in another channel of the CD, as it is a continuous sound, we used the noise itself as a reference. The output of each channel was calibrated using the VU-meter of the audiometer. Either the pure tone, present in the channel one, and the noise, present in the channel two, were put in level zero.

\section{Selection of the experimental group}

Participated on this research only individuals who agreed to perform the necessary procedures for the implementation of the research and who signed the Statement of Consent, after receiving information about the goal and methodology of the proposed study.

The inclusion criteria were: high school concluded, age between 45 and 76 years-old, audiometric thresholds indicative of bilateral sensorineural hearing loss and symmetrical moderate level (averaging between 41 and 55 tritone dB HL) (6) and having no experience in use of hearing devices.

Exclusion criteria were: presence of neurological changes, articulatory and/or verbal fluency; audiological diagnosis of hearing loss conductive or mixed; compromised middle ear; presence of stopper cerumen or other in the external auditory canal, capable to change the performance on the test; and any difficulty/ limitation which could imped to respond to the test Portuguese Sentences Lists (PSL).

Total, 50 individuals who met the inclusion criteria were evaluated. Among them, 16 adults in the middle-age, with average age57,94 years-old; and 34 elderly, with average age of 67,21 years-old.

\section{Evaluation}

\section{Anamnesis}

The anamnesis was performed by a questionnaire consisting of closed questions, in which the studied individuals provided information about personal data, level of education, profession, daily habits, otological history and auditory complaints.

\section{Basic Audiological Evaluation}

First, we performed visual inspection of the external meatus in order to exclude from the sample individuals who present changes that are capable to interfere on the results of proposed evaluation.

Patients were submitted to basic audiological evaluation, composed of: tone threshold audiometry (PTA) by air conduction at frequencies from 0.25 to $8 \mathrm{kHz}$ and by bone conduction at frequencies from 0,5 to $4 \mathrm{kHz}$; research of speech recognition threshold (SRT) with dissyllabic words (7); and research the percentage index of speech recognition (PISR) with monosyllabic words.

\section{Obtaining recognition threshold of sentences}

After the individuals being submitted to anamnesis and to the basic audiological evaluation, it was obtained, in free field, in binaural, theirs Sentence Recognition Thresholds in Silence (SRTS) and in noise (SRTN). For this purpose, it was applied the test PSL (4), which it's composed of: a list of 25 sentences in Brazilian Portuguese, denominated list 1A (8); and seven lists with 10 sentences each, denominated 1B to 7B (9); and a noise with speech spectrum (10-11).

The sentences and the noise, recorded in CD, and independent channels, it was presented through a CD Player Digital Toshiba brand, model 4149, engaged to the audiometer and speakers as described. We chose to perform the research in free field in presence and in absence of competitive noise, as this is the environment which is closed to daily speaking situation.

It was used different sentences lists, one for each test condition, in order to eliminate the possibility to improve the performance due to memorization of the sentences. The use of different lists were not considered as a variable, as the lists applied on this research were equivalent (12).

The response requested to the individual evaluated was to repeat each sentence, right after the presentation of it, in the way he had understood. A response was considered correct just when the individual repeated, without errors or omissions, the whole sentence presented.

The strategy use to research the SRTS and SRTN was sequential or adaptive, or even ascending-descending (13). This strategy consists in the stimulus presentation in a determined condition - when the response is correct, decreases the intensity of the following stimulus presentation and when the response is incorrect, the intensity of the 
next stimulus is increased. It is recommended to use intervals of $4 \mathrm{~dB}$ until the first change response and, subsequently, the difference of the stimuli interval between each presentation should be of $2 \mathrm{~dB}$, until the end of the list (13). However, considering that the equipment used in this present research did not presented the possibility of 04 and $02 \mathrm{~dB}$ of intervals, being used intervals of 05 and 2,5 $\mathrm{dB}$ respectively.

This evaluation was performed in this following sequence: training without competitive noise, research of SRTS, research of SRTN and calculation of signal / noise relation $(\mathrm{S} / \mathrm{R})$.

For training conducted to familiarize the subject with the test, it was presented sentences from 01 to 10 of the list 1A, without competitive noise. It is important that these measures start in a condition in which the individual is capable to recognize correctly the first sentence of each list, in order to have better understanding of the dynamics of the test and also to reduce variables. Therefore, to ensure this condition, the inicial presentation intensity of the sentences in silence, for the training list, it was from 20 $\mathrm{dB}$ above the SRT of the better ear (14).

The measures obtained in the training were not considered in the analysis of research result, but to determine the intensity that would be used to present the first sentence of the list, which results would be studied.

After the training, we presented the list 1B, without presence of noise, and the levels of the sentence presentation were noted, in order to calculate an average, obtaining the SRTS.

Next, the sentences from 11 to 20 of the list $1 \mathrm{~A}$ were presented to training with presence of constant competitive noise at $65 \mathrm{~dB}$ SPL (A).

Considering that each individual with hearing loss could present skills to recognize the speech in noise in relation $\mathrm{S} / \mathrm{N}$ variable, the training served for the individual familiarize with test and to verify the inicial S/N aproximate relationin order to start the research of SRTN, making the necessary adjustment to Begin the test in a $\mathrm{S} / \mathrm{N}$ relation in which they were capable to answer correctly the first sentence of each list, also in noise.

The following list applied was $2 \mathrm{~B}$ list, with presence of competitive noice at fixed intensity of $65 \mathrm{~dB}$ SPL (A) in free field. This noise intensity was used as it is the most similar to communication situation in presence of competitive noises (15). In the same way for obtaining SRTS, for SRTN, the level of presentation of the sentences were also noted to calculate the average later. The value of SRTN obtained was deducted from the level of the presented noise, obtaining the relation $\mathrm{S} / \mathrm{N}$.

\section{Calculation of Results}

The level presentation of each sentence were noted during the test. The average value was calculated from the presentation level in which occurred the first change in the type of answer (right / wrong), until the value of last sentence of the list presented.

For obtaining the relation $\mathrm{S} / \mathrm{N}$, we deducted the intensity level of the noise presentation from the average intensity value of the sentences presentation. Thus, it was characterized that the relation $\mathrm{S} / \mathrm{N}$ corresponds to the difference, in $\mathrm{dB}$, between the value of SRTN and the value of competitive noise.

\section{Statistical analisys}

Analyzed variables in this study were: tritone mean of the better ear (once the recognition thresholds of sentences were obtained in free field, it is assumed that this is the answer), SRTS in relation $\mathrm{S} / \mathrm{N}$.

After calculate these variables, they were analyzed, compared and statistically correlated. It has been found that the data had normal distribution, from the normality test of Lilliefors. In order to compare the results between adults and elderly, it was used the Test $t$, which did not found statistically significant difference to SRTS, showing that both for adults and elderly had similar performance. Thus, the related data to SRTS will be gathered in a single group and analyzed in general. As to the relation $\mathrm{S} / \mathrm{N}$, it has been found statistically significant difference between the groups. Therefore, this data will be analyzed and discussed by group as well.

In order to correlate the SRTS and the tritone mean of the better ear, we used the Pearson Correlating test.

It was considered the significant result $\mathrm{p} \leq 0,05$, with confidence interval of $95 \%$. The significant results were marked with an asterisk (*) in the tables.

Also, it was performed adescriptive analisys of data, exposing the averages, minimum and maximum values found on the variables SRTS and relation $\mathrm{S} / \mathrm{N}$

\section{RESULTS}

In the Tables 1 e 2, there are presented the minimum, maximum and medium values, in $\mathrm{dB}$ SPL A; the result of the Test $t$, which compared the results between 
adults and elderly, to the variables SRTS and relation S/N respectively.

As to Table 3, there are exposed the results of the Person Correlation Test, between SRTS and the tritone mean of the better ear.

\section{DISCUSSION}

Since it was not found any statistically significant difference in comparing the results of SRTs between adults and elderly, these data will be gathered in a group and analyzed in general form. However, it was found statistically significant difference between the groups to the relation S/ $\mathrm{N}$, showing that the elderly had worst performance in this task. Thus, the results for $\mathrm{S} / \mathrm{N}$ will be analyzed and discussed separately as well.

The following, the results obtained in this study were compared with the research found in the literature, performed with individuals with normal hearing and/or with hearing loss, in free field condition. Thus, it was proposed to discuss the aspects which influenced the skills of the individual in recognizing speech, in both silence and noise.

It is important to highlight that, despite of this present research had not been performed with normal hearing subjects, it will be discussed and correlated also with the research results that evaluated this population, for so you can make an analogy to the different conditions of hearing and, then, scale the difficulty that the individuals with hearing loss presented to communicate themselves.

\section{Sentence Recognition Thresholds in Silence (SRTS)}

The results obtained in this study, as well as the finding in others research (16-18), shows the relation between average tone threshold of 0,5, 1 e $2 \mathrm{kHz}$ with the STRS of the subject, may soon be used as a reference for the interpretation of these data. One of them (18) also states that the tritone average would have a good relation with the forecast of the SRTS and that the threshold of audibility is the unique parameter to influence the silence recognition.

It was observed that individuals with moderate level of hearing loss, evaluated in this study, presented the mean values of SRTS of $60.90 \mathrm{~dB}$ SPL (A), having had a variation from $38.35 \mathrm{~dB}$ SPL (A) to $71.05 \mathrm{~dB}$ SPL (A).

Some researchers $(3,8,15,19-22)$ evaluated the SRTS of normal hearing adults, in free field, respectively, the
Table I. Minimum, maximum values and the averages, in $\mathrm{dB}$ SPL (A), to the variable SRTS; and the p value comparing between adults and elderly.

\begin{tabular}{lcccc}
\hline Variables & Minimum & Maximum & Average & pValue \\
\hline Adults & 41,67 & 71,05 & 58,66 & 0,1259 \\
Elderly & 38,36 & 70,78 & 62,04 & \\
\hline All of the subjects & 38,35 & 71,05 & 60,90 & \\
\hline
\end{tabular}

Table 2. Minimum, maximum values and the averages, in $\mathrm{dB}$ $\operatorname{SPL}(\mathrm{A})$, to the variablerelation $\mathrm{S} / \mathrm{N}$; and thep value comparing between adults and elderly.

\begin{tabular}{lcccc}
\hline Variables & Minimum & Maximum & Average & pValue \\
\hline Adults & $-0,89$ & 6,47 & 2,43 & $0,0447 *$ \\
Elderly & $-1,16$ & 6,33 & 3,61 & \\
All ofthesubjects & $-1,16$ & 6,47 & 3,20 &
\end{tabular}

*Statistically significant

Table 3. Correlation between SRTS and tritone mean of the bestear.

\begin{tabular}{l}
\hline Variables SRTS Tritone mean \\
\hline Mean $\quad 60,96 \quad 48,23$ \\
Correlationcoef. $\mathrm{p}=0,046$ I* \\
*Statistically significant
\end{tabular}

values of $26,80 \mathrm{~dB} A, 17,15 \mathrm{~dB} A, 23,91 \mathrm{~dB} A, 15,75 \mathrm{~dB} A$, $32,90 \mathrm{~dB}$ A, 27,40 dB A and 23,61 dB A.

Of these, some $(3,19-20,22)$ researched the SRTS also in adults individuals bearer of sensorineural hearing loss, in free field, and obtained, respectively, the average values of $38,30 \mathrm{~dB} A, 52,32 \mathrm{~dB} A, 52,10 \mathrm{~dB}$ A and $35,20 \mathrm{~dB}$.

Initially analyzing the results, it can be verified that the values found in the present research were above from those obtained in the studies cited, especially if compared to those who assessed normal hearing subjects, what was expected, once the individuals studied here presented hearing loss.

This shows that, even in silence situation, individuals with moderate level of auditory loss can present accentuated difficulty recognizing speech. Besides increasing the intensity, for a good performance in the hearing speech of the individuals with hearing loss are necessary other resources, such as aid of lip reading and contextualization of what is spoken.

This worst performance recorded, even in silence, through LSP in individuals with hearing loss, shows the relevance of the use of sentences as stimulus in order to 
evaluate the patients in communication situation, instead of worry about in make a prognosis of these situations as a base to audiometric thresholds.

Also it was observed a range of variation big enough (of 32,7 dB SPL (A)) between the individuals which presented the best and worst answers, whereas in the research with normal hearing individuals, we observed a maximum variation amongst the subjects around $14 \mathrm{~dB} \mathrm{SPL}$ (A) (14).

This great variability obtained in the answers with hearing loss was expected, even if all them present the same degree of hearing loss, as it is known that the classification employed considers only the tone thresholds of frequencies $0,5,1$ and $2 \mathrm{kHz}$.

Since variation occurs in the remaining frequencies for each subject, it can interfere on individual results, since these other frequencies are important for discrimination of what is heard. Even having lowered thresholds only in the acutes frequencies, it is expected a much more poor speech recognition, as with it, it is lost many sounds, phonological information and auditory clues, in which are intact in subjects with better thresholds at frequencies from 3 to $8 \mathrm{kHz}$.

The sensorineural hearing loss presents five deficits associated: threshold elevation, reduction of dynamic range / loudness, reduction in frequency selectivity, reduced temporal resolution and binaural processing changed (23).

Speech is an acoustic signal which information is transmitted through changing the relation of frequency, intensity and time. The normal auditory system has inherent capacity to identify, process and code this information. This way, any degradation on the capacity of auditory system in performing these functions can lead to a decline on the capacity of speech understanding in certain communication situation of the hearing impared.

Thus, the individual with moderate loss many times can not dimension the hearing difficulty in silence situation, as if he has visual clue, an eloquent enough interlocutor and a contextualized conversation, he will have a quite satisfactory communication, believing that he does not possess hearing loss which justifies intervention. This way, the difficulty can be dimensioned and showed to the patient, based on a test that offers a condition which simulate a situation of conversation, but, without visual clue and context.

And thus, with the data obtained in the evaluation, the patient and/or your relatives can, upon seeing the difference of the results and the data obtained with normal hearing individual, understand better how his condition is below the desired to a real satisfactory communication.

\section{Relations Signal / Noise (S/N), obtained through the Sentence Recognition Thresholds in Noise (SRTN)}

It was found difference statistically significant in comparison between the results of adults and elderly, suggesting that the adults had a better performance than the elderly. This result is consitent with the reported in another study (25), which refers that the aging process does not affects only the hearing in peripheral way. The changes are associated to the central auditory processing, that concer the important skills to comprehend the speech, especially in adverse listening environments.

Authors (26) stated that the difficulties of speech comprehension in elderly cannot be associated to the loss of peripheral hearing, since there are cases in elderly with little difficulties to detect sounds with low intensity but they claim having difficulties to understand speech. This way, the individuals with the same hearing loss can have different performances.

However, despite of the difference the values found between adults and elderly have been statistically significant, it was observed that the numerical difference is small, of 1,18. Therefore, also it will be performed analisys in general, as discussed in similar research (25).

The mean $\mathrm{S} / \mathrm{N}$ relations obtained for all of the subjects in this study were +3.20 DB SPL (A) ranging from $-1.16 \mathrm{~dB}$ SPL (A) to $+6.47 \mathrm{~dB}$ SPL (A). Certain authors (3,8,14-15,19-22,27-29) evaluated normal hearing adults, in free field with noise in fixed intensity, and obtained the relations Signal / Noise (S/N) of $-6.4 \mathrm{~dB} A,-10.33 \mathrm{~dB} A$, A $-8.14 \mathrm{~dB},-2.92 \mathrm{~dB}$ A, $\mathrm{A}-2.6 \mathrm{~dB},-12 \mathrm{~dB}$ A, the $-6 \mathrm{~dB},-6.71$ $\mathrm{dBA}$, The $-11.5 \mathrm{~dB},-8.72 \mathrm{~dB}$ and $-7.57 \mathrm{~dB}$ A, respectively.

From these, some $(3,19-20,22,29)$ also evaluated, individuals with sensorineural hearing loss in the same conditions and obtained Relations Signal / Noise $(\mathrm{S} / \mathrm{N})$ of $3,7 \mathrm{~dB} A,+1,34 \mathrm{~dB} \mathrm{~A},+2,1 \mathrm{~dB} \mathrm{~A}-1,15 \mathrm{~dB} \mathrm{~A}-2,1 \mathrm{~dB} \mathrm{~A}$.

In this present research, observed that the individuals with moderate degree of hearing loss were capable to recognize around of $50 \%$ of the speech stimuli when they were presented to a medium intensity of $3,20 \mathrm{~dB}$ A above the noise intensity, which was presented in fixed intensity of $65 \mathrm{~dB}$ SPL (A).

If we compare these findings with the cited that evaluated the individuals with normal hearing and that 
used the same test material, with the same strategy, it was observed that the individuals with normal hearing, who presented SRTS in a relation S/N - 8,14 dB SPL (A) (14), were capable to recognize round of $50 \%$ of the same sentences also in the presence of a competitive noise fixed in $65 \mathrm{~dB}$ SPL (A), in the speech medium intensity round of $8 \mathrm{~dB}$ below the noise intensity and, so, 11,34 dB SPL (A) lower than necessary to the subjects in this present study.

In order to dimension what means the relation $\mathrm{S} / \mathrm{N}$ from $+3,20$ to $-8,14 \mathrm{~dB}$ SPL (A) in a communication situation, we can cite the study (29) which observed that to each $1 \mathrm{~dB}$ of variation in the relation $\mathrm{S} / \mathrm{N}$ there is a change of $12,12 \%$ in the Percentage Index Sentence Recognition in Noise (IPRSR).

We can find on the literature other authors who also investigated the change effects of relation $\mathrm{S} / \mathrm{N}$ and found values even greater than of each $1 \mathrm{~dB}$ of variation. One of the studies refers to this change is of $18-20 \%$ in the intelligibility of the sentences in noise (30). In another study, such difference in the SRTS corresponded to $18 \%$ of the change in the IPRSR (31).

Therefore if, an individual with normal hearing is capable to recognize $50 \%$ of the information with speech on average $8 \mathrm{~dB}$ lower than the noise intensity and, the subjects here analyzed, needed that the speech were on average about $03 \mathrm{~dB}$ above the noise intensity, to perform the same task, and if, to each change of $1 \mathrm{~dB}$ in the relation $\mathrm{S} / \mathrm{N}$, the individual has a worsening in speech recognition about of $12 \%$ (29) in a situation of noisy communication, as it is common in our day to day, the most of the individual with hearing loss will not have any possibility of recognizing speech (32) in the situation that the subject with normal hearing could.

The situation of listening in unfavorable enviroment is too hard with hearing loss, since by lowering the threshold, even in silence, hear what is told already demands a greater effort, with the increase of background noise, he will need to use another skills to do the relation of which of these complex sounds he must recognize in order to comprehend the interested message.

The skill to recognize speech, in the presence of other sound, is one of the most important capacity to the communication and, also it is, one of the most susceptible to damage, due to hearing loss (33).

Another aspect observed when analyzed and compared to the obtained results among the different researchers, who did not used the same material and procedures, to either individuals with normal hearing and with hearing loss, it was the great variability on the obtained answers in the different studies, and probably it can be explained by number of factors that are discussed below.

Initially we can cite some variables found in the speech test performed in free field, that interfere on the measures, such as: room size, acoustic conditions, existence of reflective surfaces, reverb level, number of people in the test enviroment, speech intelligibility of the speaker, difficulty level of the sentences versus socio-cultural level of the individuals tested, environment conditions where the research was performed and the equipment calibration $(1,23,34)$.

Another aspect to be considered is that some tests were developed in different languages, therefore, linguistic factors, language experiences and language proficiency, can influence the results (35).

Moreover, the masking effect of noise to speech stimuli used by each researcher influences considerably on the answers.

Another consideration to be done is with the relation of the individual differences of each group studied. It was observed in this present research that there was a variation in the relation S/N from -1,16 dB NPS (A) to $+6,47 \mathrm{dBNPS}$ (A), which means a difference of 7,63 dB NPS (A) among the subjects with sensoneural hearing loss.

Comparing with literature we can also observe a similar variability, even amongst the individuals with normal hearing.

There are some factors that can interfere on the answers of speech recognition evaluation, like: motivation, interest, intellectual and educational level, age, the familiarity with used words and the patient stress level

It is important to highlight the performance in speech test in noise presence cannot be only justified by the tone thresholds (37), thus, besides the presence of audiometric thresholds out of normal range, the possible differences found it is due to the percentage deficits associated to the sensoneural hearing loss: reduction of dynamic range / loudness, reduction in frequency selectivity, reduction of temporal and binaural processing changed (23), as it has been already discussed before.

It should consider the age of the individuals evaluated in this study, which varied from 45 to 76 years-old, since it is understood that the performance in elderly is inferior than the younger with similar hearing thresholds, which shows that the others factor are involved in speech 
recognition in noise, beyond the sensitivity of the auditory peripheral organ (38).

The age factor deserves special attention, as the increasing age can affect in various ways - among the more common complaints are the speakers who seem to mumble or speak too fast. The elderly report that it is difficult to keep up a dialogue, especially in noisy enviroment, when there are several speakers or when there is changing of speaker of theme (39).

Recent studies have shown that the difficulties with speech recognizing may be related to the loss of ability to perform temporal processing of sounds associated with aging (26).

It is common to find in the practice of clinical audiologist, subjects that presente similar tone auditory thresholds, but they possess different skills of speech perception in unfavorable listening situations (24).

This study give us an idea of how a group with determined hearing loss behaves in communication situation, and these observed differences among the subjects evaluated allowed to state that the inclusion of test in free field, using sentences as stimulus, with or without background noise, after basic audiological evaluation in subjects with hearing loss, enable us obtaining answers that go beyond of skills to detect the presence of pure tones and recognizing isolated words.

These tests evaluate the patient as a whole, when simulate communicative situations, providing data about the abilities and limitations of each individual, which determine the communication capacity.

We should highlight that the method used in this study represents a reference to clinical activity from the material used, also seeking to encourage research that may give continuity to the studies that will contribute to the advance of speech tests and, thus, collaborate in relation to the conduct to be followed in cases of individuals with hearing disorders.

\section{CONCLUSION}

At the end of this research, the analisys of the variables enabled to conclude that the SRTS average obtained was of $60,90 \mathrm{~dB}$ SPL (A) and that it was correlated with the average of the best ear tritone, what the threshold of audibility seems to be the only parameter that influence in recognizing silence. Moreover, we could concluded that the average relations $\mathrm{S} / \mathrm{N}$ found was of + 3,20 dB SPL (A), showing the difficulty that the subject presents with hearing loss in daily communication, in noisy enviroment.

\section{BiBLIOGRAPHY REFERENCES}

1. Schochat E. Percepção de fala. In: Schochat E. (org.) Processamento Auditivo. São Paulo: Lovise; 1996, pp.15-42.

2. Kalikow DN, Stevens KN, Elliot LL. Development of a test speech intelligibility in noise using sentence materials with controlled word predictability. J Acoust Soc Am. 1977, 61:1337-51.

3. Bronkhorst AW, Plomp RA. Clinical test for the assessment of binaural speech perception in noise. Audiology. 1990, 29:275-85.

4. Costa MJ. Listas de sentenças em português: apresentação e estratégias e aplicação na audiologia. Santa Maria: Pallotti; 1998.

5. Boothroyd A. Speech perception, sensorioneural hearing loss and hearing aids. In: Studebaker G, Hochberg I. Acoustical factors affecting hearing aid performance. $2^{\underline{a}}$ ed. Boston: Allyn \& Bacon; 1993, pp. 277-99.

6. Silman S, Silverman CA. Auditory diagnosis, principles and applications. London: Singular Publishing Group; 1991.

7. Mangabeira-Albernaz PL. Logoaudiometria. In: Pereira LD, Schochat E. Processamento auditivo central. Manual de avaliação. São Paulo: Lovise; 1997.

8. Costa MJ, Iorio MCM, Mangabeira-Albernaz PL. Reconhecimento de fala: desenvolvimento de uma lista de sentenças em português. Acta Awho. 1997, 16(4):164-73.

9. Costa MJ. Desenvolvimento de listas de sentenças em português. São Paulo, 1997. (Tese de Doutorado-Distúrbios da Comunicação Humana da Universidade Federal de São Paulo).

10. Costa MJ, Iorio MCM, Mangabeira-Albernaz PL, Cabral Jr EF, Magni AB. Desenvolvimento de um ruído com espectro de fala. Acta Awho. 1998, 17(2):84-89.

11. Jonge R. Selecting and verifying hearing aid fittings for simmetrycal hearing loss. In: Valente M. Strategies for selecting and verifying hearing aid fittings. New York: Theme Medicals Publishers Inc.; 1994.

12. Santos SN, Daniel RC, Costa JC. Estudo da equivalência entre as listas de sentenças em português. Rev CEFAC. 2009, 11(4):673-80. 
13. Levitt H, Rabiner LR. Use of a sequencial strategy in intelligibility testing. J Acoust Soc Am. 1967, 42:60912 .

14. Henriques MO, Miranda EC, Costa MJ. Limiares de reconhecimento de sentenças no ruído, em campo livre: valores de referência para adultos normo-ouvintes. Rev Bras Otorrinolaringol. 2008, 74(2):188-92.

15. Nilsson MJ, Soli SD, SullivanJ. Development of the hearing in noise test for the measurement of speech reception threshold in quiet and in noise. J Acoust Soc Am. 1994, 95:1085-99.

16. Soncini F, Costa MJ, Oliveira TMT, Lopes LF. Correlação entre limiares de reconhecimento de sentenças no silêncio e limiares tonais. Rev Bras Otorrinolaringol. 2003, 69(5):67277.

17. Aurélio NHS, Becker KT, Padilha CB, Santos SN, Petry T, Costa MJ. Limiares de reconhecimento de sentenças no silêncio em campo livre versus limiares tonais em fone em indivíduos com perda auditiva coclear. Rev CEFAC. 2008, 10(3):378-84.

18. Wong LL, Cheung C, Wong EC. Comparison of hearing thresholds obtained using pure-tone behavioral audiometry, the Cantonese Hearing in Noise Test (CHINT) and cortical evoked response audiometry. Acta Otolaryngol. 2008, 128(6):654-60.

19. Nilsson M, Soli SD, Sumida A. Development of norms and percent intelligibility functions for the HINT. House Ear Institute. 1995, pp. 1-9.

20. Kramer SE, Kapteyn TS, Festen JM, Kuik DJ. Assessing aspects of auditory handicap by means of pupil dilatation. Audiology. 1997, 36(3):155-64.

21. Ribeiro AF. Adaptação dos resultados das listas de sentenças com ruído e seus benefícios na prática clínica. Goiânia, 1999. (Monografia de Especialização-Centro de Especialização e Fonoaudiologia Clínica-CEFAC).

22. Pagnossim DF, Iorio MC, Costa MJ. Reconhecimento de sentenças em campo livre em indivíduos portadores de perda auditiva neurossensorial. Jornal Brasileiro de Fonoaudiologia. 2001, 2:153-59.

23. Naylor G. Technical and audiological factors in the implementation use of digital signal processing hearing aids. Scand Audiol. 1997, 26(4):223-29.

24. De Paula A, Oliveira JAP, Godoy NM. Baixa discriminação auditiva em ambiente competitivo de pacientes jovens com audiograma normal. Rev Bras Otorrinolaringol. 2000, 66(5):439-42.

25. Soncini F, Costa MJ, Oliveira TMT. Influência do processo de envelhecimento no reconhecimento da fala em indivíduos normo-ouvintes. Pró-fono. 2003, 15(3):287-96.

26. Neves VT, Feitosa MAG. Controvérsias ou complexidade na relação entre processamento temporal auditivo e envelhecimento? Rev Bras Otorrinolaringol. 2003, 69(2):1-11.

27. Wezl-Muller K, Sattler K. Signal-to-noise threshold with and without hearing aid. Scand Audiol. 1984, 13(4):283-86.

28. Miranda EC, Costa MJ. Reconhecimento de sentenças no silêncio e no ruído de indivíduos jovens adultos normoouvintes em campo livre. Rev Fonoatual. 2006, 35(8):412 .

29. Henriques MO. Limiares e índices percentuais de reconhecimento de sentenças no ruído, em campo livre, para indivíduos adultos. 2006. (Dissertação de Mestrado em Distúrbios da Comunicação Humana-Universidade Federal de Santa Maria).

30. Middelweerd MJ, Festen JM, Plomp R. Difficulties with speech intelligibility in noise in spite of a normal pure-tone audiogram. Audiology. 1990, 29(1):1-7.

31. Smoorenburg GF. Speech reception in quiet and in noisy conditions by individuals with noise -induced hearing loss in relation to their tone audiogram. J Acoust Soc Am. 1992, 91(1):421-37.

32. Wagener KC. Factors influencing sentence intelligibility in noise. Oldenburg; Bibliotheks - und information siystem der universität Oldenburg. 2004.

33. Soli SD, Nilsson M. Assessment of communication handicap with the HINT. Hear instrumm. 1994, 45(2):14-16.

34. Festen JM, Plomp R. Effects of fluctuating noise and interfering speech on the speech-reception treshold for impaired and normal hearing. J Acoust Soc Am. 1990, 4:172536.

35. Wilson RH, Strouse AL. Audiometria com estímulos de fala. In: Musiek FE, Rintelmann NF. Perspectivas atuais em avaliação auditiva. São Paulo: Manole, 2001, pp. 21-54.

36. Pereira LD. Audiometria verbal: teste de discriminação vocal com ruído. São Paulo, 1993. (Tese de Doutorado em Distúrbios da Comunicação Humana-Universidade Federal de São Paulo). 
37. Calais LL, Russo ICP, Borges ACLC. Desempenho de idosos em um teste de fala na presença de ruído. Pró-Fono Revista de Atualização Científica. 2008, 20(3):147-52.

38. Caporali AS, Silva JA. Reconhecimento de fala no ruído em jovens e idosos com perda auditiva. Rev Bras Otorrinolaringol. 2004, 70(4):525-32.
39. Schneider BA, Daneman M, Pichora-Fuller MK. Listening in Aging Adults: From Discourse Comprehension to Psychoacoustics. Canadian Journal of Experimental Psychology. 2002, 56(3):139-52. 